\title{
Impact Resistance of High-Performance Steel Fiber Concrete under Long Term Exposure to Environmental Conditions
}

\author{
Abdulhameed Umar Abubakar, Tulin Akçaoğlu and Khaled Marar \\ Department of Civil Engineering, Eastern Mediterranean University, Gazimagusa, North Cyprus, Mersin 10 Turkey
}

\begin{abstract}
An investigation is presented here that studied the influence of long-term environmental conditions exposure on cylindrical specimens after initial 28 day moist curing. The specimens were tested after six months subjected to Mediterranean weather elements in North Cyprus. Specimens with $150 \mathrm{~mm}$ diameter by $60 \mathrm{~mm}$ long cylinders were tested under impact load using a modified version of the testing equipment described in ACI 544.2R. Numbers of blows to create first and damage cracks were determined, and subsequently the impact energies calculated. It was seen that there is as much as twenty times improvement in impact energy of fibered concretes at fiber volume of $2 \%$ when compared with plain concrete. This will go a long way to improve the impact resistance of industrial floors and slabs on grade.
\end{abstract}

\section{Introduction}

\subsection{Background}

It is known that the addition of discrete discontinuous fibers to concrete helps in increasing the ductility as a result of the resistance to pull-out offers by the fibers. Over the years, various types of fibers of different forms and geometries have been successfully applied to concrete making process with measured success. These include steel fibers, natural fibers, polymer fibers, glass and synthetic etc. In respect of steel fibers, they come in different geometries such as straight, deformed, machined chip, hooked-end etc. and are regulated by ASTM A820 which establishes the tolerance limits for aspect ratio (length-to-diameter), and ability of the fiber to bond properly is dependent on the aspect ratio which ranges from $20-100$.

In the application of steel fiber concrete, there are some important terms to ponder upon as defined in ACI 544.1R [1] such as first crack strength which is the maximum stress that a material is capable of developing without deviation from linearity. Toughness which is the area under the load - deformation curve obtained from flexural strength test up to a known deflection. The energy required to crack a standard specimen of known dimension under impact conditions is known as the impact strength.

Some studies reported in ACI 544.1R [1] stated that the peak loads in high-strength steel fiber-reinforced concrete were as much as $40 \%$ higher than that of the plain concrete, and the fracture energy under impact is increased by a factor of as much as 3.5 times. In [2] it was reported that an increase in as much as 80 times is observed when $5 \%$ silica fume is used with $2 \%$ fiber volume having aspect ratio 83. The work of [3] investigated the relationship between compression toughness and impact energy for high-strength fiberreinforced concrete, and reported a logarithmic relationship existing between them. The work of [4] conducted a statistical analysis on impact strength for first crack, failure strength and reliability strength on a hybrid steel-polypropylene fiber-reinforced concrete with a drop-weight hammer. They reported a slight improvement in hybrid fiber-reinforced concrete compared with the conventional steel fiber concrete. The use of mixed aspect ratio fibers on steel fiber concrete has been explored on $100 \times 100 \times 500 \mathrm{~mm}$ beams by impact loading. It was seen that longer fibers gave a better performance especially at $2.0 \%$ fiber volume. Some researchers [5] reported on the use of hybrid oil palm shell fiber concrete utilizing steel and polypropylene at different fiber volume to test the impact strength using a $10 \mathrm{~kg}$ drop weight hammer over a height of $0.6 \mathrm{~m}$ with a panel specimen.

This study is devoted to the investigation of impact str ength of a cylindrical specimen of known dimension that has undergo different cycles of curing beyond the age of 28 days subjected to impact load of $13.5 \mathrm{~kg}$ hammer.

\subsection{Significance of the study}

In this study, the influence of environmental conditions mimicking the actual condition that the concrete would be subjected to while in service. Concrete specimens were exposed to weather elements after initial moist curing for 28 days. Previous studies have focused mostly on the 28 days resistance, and we believe that a study that investigate the effect of long term curing under different 
conditions is relevant and increase our knowledge in the subject area.

\section{Experimental procedure}

\subsection{Materials}

Blast-furnace Slag Cement CEM II/B-S $42.5 \mathrm{~N}$ that conforms with ASTM C 595-17 having a specific gravity of 3.15 and silica fume with $95 \% \mathrm{SiO}_{2}$ content was utilized at $10 \%$ of the cement content. Tap water was utilized which conform to BS EN 1008-02, and a high range water reducer GLENIUM 27 conforming with ASTM C 494 brown in colour was applied. Aggregates used were crushed limestone rock conforming to the specification of ASTM C 33 and sieve analysis was conducted in accordance with ASTM C 136 and the result presented in Table 1. Relative density (SSD) performed for both fine and coarse aggregates were based on ASTM C 127 and ASTM C 128 and were 2.68 and 2.85 respectively, also absorption (\%) determined based on the same standards were $3.0 \%$ and $0.7 \%$. Bulk density was based on ASTM C 29 were $2083 \mathrm{~kg} / \mathrm{m}^{3}$ and $1203 \mathrm{~kg} / \mathrm{m}^{3}$. Voids in aggregates were $25 \%$ and $50 \%$ respectively for fine and coarse aggregates. The percentage of materials finer than $75 \mu \mathrm{m}$ to ASTM C117 was $13 \%$. Overall, the mix design used in this study is presented in Table 2 with constituents given in $\mathrm{kg} / \mathrm{m}^{3}$.

Hooked end steel fiber based on the specification of A STM A820 with a length of $30 \mathrm{~mm}$, diameter of $0.5 \mathrm{~mm}$ a nd tensile strength of $1250 \mathrm{MPa}$ was used.

\subsection{Methods}

Mixing operation was done as prescribed for steel fiber in ACI 544.1R [1] with fiber additions at 0, 0.50, 0.75, 1.00 $, 1.25,1.50,1.75$, and $2.00 \%$ by volume. Specimens prep ared for impact test were produced from $150 \mathrm{~mm}$ by 300 $\mathrm{mm}$ cylinders subjected to the weather elements from late June 2017 to early January 2018 approximately 6 months . However, the specimens were first moist cured in the cu ring tank at the initial 28 days before placing them outsid e the laboratory at a good spot subjected to environmental conditions. The specimens were then cut into $150 \mathrm{~mm}$ by $60 \mathrm{~mm}$ cylinders using a $3 \mathrm{~mm}$ thick power saw, five spe cimens were produced from each single cylinder and the $\mathrm{t}$ wo ends of the specimen were thrown away to have simil ar end conditions in all the specimens utilized as can be $\mathrm{s}$ een in Fig. 1. Apparatus utilized for the impact test was a modified version of a drop weight hammer (Fig. 1a) deve loped in the department based on the recommendations of ACI 544.2R [6] and described in detail in [2 3]. It consists of a $13.5 \mathrm{~kg}$ hammer weight falling over a height of $0.3 \mathrm{~m}$. The impact energy (E) is calculated from the following formula:

$$
\text { Impact energy, } \mathrm{E}(\mathrm{Nm})=\operatorname{mgh} . \mathrm{N}
$$

Where

$\mathrm{m}$ is the mass of the hammer $(\mathrm{kg}), \mathrm{g}$ is the acceleration due to gravity $\left(9.82 \mathrm{~m} / \mathrm{s}^{2}\right), \mathrm{h}$ is the height of drop hammer (m), and $\mathrm{N}$ is the number of blows either to reach first visible crack or cause substantial damage to the specimen called damage crack.

The number of impact to produce either the first or da mage crack is recorded, and the impact energy calculated. The mean of the impact energies were calculated as a res ult of the significant variations observed in the first crack number of blows.

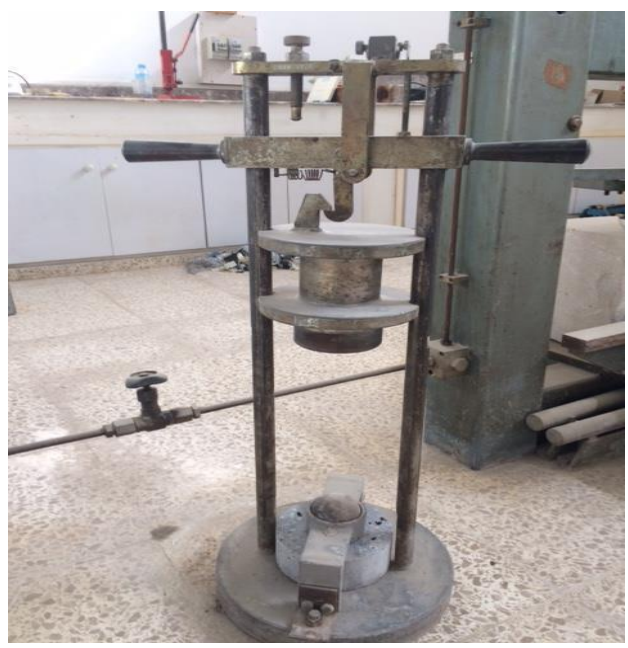

Figure 1a. Modified drop weight impact testing machine

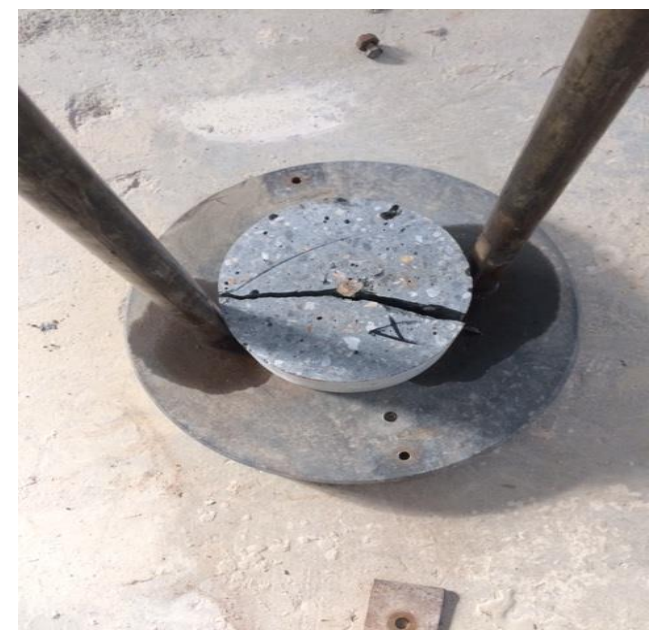

Figure 1b. Damage crack in control specimen (0\% fiber)

Table 1. Sieve analysis of aggregates.

\begin{tabular}{lccccccccc}
\hline Sieve sizes $(\mathrm{mm})$ & 12.5 & 9.5 & 4.75 & 2.36 & 1.18 & 0.6 & 0.3 & 0.15 & 0.075 \\
\hline \% passing coarse & 100 & 100 & 9.4 & 0.2 & 0.2 & - & - & - & - \\
\% passing fine & - & - & 100 & 82 & 48 & 29 & 17 & 7 & 3 \\
\hline
\end{tabular}


Table 2. Mix design utilized for HPSFC.

\begin{tabular}{|c|c|c|c|c|c|c|}
\hline Material & Cement & Water & $\begin{array}{c}\text { Coarse } \\
(0-10 \mathrm{~mm})\end{array}$ & $\begin{array}{c}\text { Fine } \\
(0-5 \mathrm{~mm})\end{array}$ & $\begin{array}{l}\text { Silica } \\
\text { Fume }\end{array}$ & HRWR* \\
\hline $\begin{array}{l}\text { Quantity } \\
\left(\mathrm{kg} / \mathrm{m}^{3}\right)\end{array}$ & 470 & 165 & 1050 & 700 & 47 & 14 \\
\hline
\end{tabular}

Table 3. Average number of blows and the relationship with impact ductile crack

\begin{tabular}{|c|c|c|c|c|c|c|}
\hline $\begin{array}{l}\text { Fiber } \\
\text { Volume } \\
(\%)\end{array}$ & Sample No. & $\begin{array}{l}\text { First } \\
\text { Crack No. } \\
\text { of Blows }\end{array}$ & $\begin{array}{l}\text { Average No of } \\
\text { First Cracks } \\
\text { Blows }\left(\mathrm{N}_{\mathrm{f}}\right)\end{array}$ & $\begin{array}{l}\text { Damage } \\
\text { Crack No. } \\
\text { of Blows }\end{array}$ & $\begin{array}{l}\text { Average No } \\
\text { of Damage } \\
\text { Crack Blows } \\
\left(\mathrm{N}_{\mathrm{c}}\right)\end{array}$ & $\begin{array}{l}\text { Impact Ductile } \\
\text { crack } \mu=\mathrm{N}_{\mathrm{f}} / \mathrm{N}_{\mathrm{c}}\end{array}$ \\
\hline \multirow[t]{3}{*}{0} & A1 & 2 & & 2 & & \\
\hline & $\mathrm{A} 2$ & 2 & 2.33 & 2 & 2.33 & 1 \\
\hline & A3 & 3 & & 3 & & \\
\hline \multirow[t]{3}{*}{0.5} & B1 & 2 & & 4 & & \\
\hline & B2 & 2 & 2 & 3 & 3.67 & 1.84 \\
\hline & B3 & 2 & & 4 & & \\
\hline \multirow{3}{*}{0.75} & C1 & 2 & & 6 & & \\
\hline & C2 & 1 & 2.33 & 6 & 6.67 & 2.86 \\
\hline & C3 & 4 & & 8 & & \\
\hline \multirow[t]{3}{*}{1} & D1 & 3 & & 19 & & \\
\hline & D2 & 5 & 4.67 & 11 & 14.67 & 3.14 \\
\hline & D3 & 6 & & 14 & & \\
\hline \multirow[t]{3}{*}{1.25} & E1 & 3 & & 20 & & \\
\hline & E2 & 7 & 7 & 17 & 21 & 3 \\
\hline & E3 & 11 & & 26 & & \\
\hline \multirow[t]{3}{*}{1.5} & $\mathrm{~F} 1$ & 4 & & 12 & & \\
\hline & $\mathrm{F} 2$ & 6 & 5.33 & 17 & 13 & 2.44 \\
\hline & F3 & 6 & & 10 & & \\
\hline \multirow[t]{3}{*}{1.75} & G1 & 7 & & 20 & & \\
\hline & G2 & 5 & 5.33 & 14 & 16 & 3 \\
\hline & G3 & 4 & & 14 & & \\
\hline \multirow[t]{3}{*}{2} & H1 & 19 & & 41 & & \\
\hline & $\mathrm{H} 2$ & 24 & 21.33 & 63 & 50 & 2.34 \\
\hline & $\mathrm{H} 3$ & 21 & & 46 & & \\
\hline
\end{tabular}

Table 4. First crack impact energies

\begin{tabular}{|c|c|c|c|c|c|c|c|}
\hline $\begin{array}{l}\text { Fiber } \\
\text { Volume } \\
(\%)\end{array}$ & $\begin{array}{l}\text { Sample } \\
\text { No. }\end{array}$ & $\begin{array}{l}\text { No. of } \\
\text { Blows }\end{array}$ & $\begin{array}{l}\text { Impact } \\
\text { Energy }(\mathrm{Nm})\end{array}$ & Mean & SE Mean & St Dev & $\begin{array}{l}\text { Impact } \\
\text { Effectiveness }\end{array}$ \\
\hline \multirow[t]{3}{*}{0} & A1 & 2 & 79.54 & & & & \\
\hline & A2 & 2 & 79.54 & 92.8 & 13.3 & 23.0 & - \\
\hline & A3 & 3 & 119.30 & & & & \\
\hline \multirow[t]{3}{*}{0.5} & $\mathrm{~B} 1$ & 2 & 79.54 & & & & \\
\hline & B2 & 2 & 79.54 & 79.54 & 0.00 & 0.00 & -0.14 \\
\hline & B3 & 2 & 79.54 & & & & \\
\hline \multirow[t]{3}{*}{0.75} & $\mathrm{C} 1$ & 2 & 79.54 & & & & \\
\hline & $\mathrm{C} 2$ & 1 & 39.77 & 92.8 & 35.1 & 60.7 & 0 \\
\hline & $\mathrm{C} 3$ & 4 & 159.08 & & & & \\
\hline \multirow[t]{3}{*}{1.00} & D1 & 3 & 119.3 & & & & \\
\hline & D2 & 5 & 198.86 & 185.6 & 35.1 & 60.8 & 1 \\
\hline & D3 & 6 & 238.63 & & & & \\
\hline \multirow[t]{3}{*}{1.25} & E1 & 3 & 119.3 & & & & \\
\hline & E2 & 7 & 278.40 & 278.4 & 91.9 & 159.1 & 1.99 \\
\hline & E3 & 11 & 437.48 & & & & \\
\hline \multirow[t]{2}{*}{1.50} & $\mathrm{~F} 1$ & 4 & 159.08 & & & & \\
\hline & F2 & 6 & 238.63 & 212.1 & 26.5 & 45.9 & 1.29 \\
\hline
\end{tabular}




\begin{tabular}{llllllll} 
& F3 & 6 & 238.63 & & & \\
1.75 & G1 & 7 & 278.40 & & & \\
& G2 & 5 & 198.86 & 212.1 & 35.1 & 60.7 & 1.29 \\
& G3 & 4 & 159.08 & & & & \\
2.00 & H1 & 19 & 755.65 & & & & \\
& H2 & 24 & 954.50 & 848.4 & 57.8 & 100.1 & 8.14 \\
\hline
\end{tabular}

Table 5. Damage crack impact energies

\begin{tabular}{|c|c|c|c|c|c|c|c|}
\hline $\begin{array}{l}\text { Fiber } \\
\text { Volume } \\
(\%)\end{array}$ & Sample No. & $\begin{array}{l}\text { No. of } \\
\text { Blows }\end{array}$ & $\begin{array}{l}\text { Impact } \\
\text { Energy }(\mathrm{Nm})\end{array}$ & Mean & SE Mean & St Dev & $\begin{array}{l}\text { *Impact } \\
\text { Effectiveness }\end{array}$ \\
\hline \multirow[t]{3}{*}{0} & A1 & 2 & 79.54 & & & & \\
\hline & A2 & 2 & 79.54 & 92.8 & 13.3 & 23.0 & - \\
\hline & A3 & 3 & 119.3 & & & & \\
\hline \multirow[t]{3}{*}{0.5} & B1 & 4 & 159.08 & & & & \\
\hline & B2 & 3 & 119.3 & 145.8 & 13.3 & 23.0 & 0.57 \\
\hline & B3 & 4 & 159.08 & & & & \\
\hline \multirow[t]{3}{*}{0.75} & $\mathrm{C} 1$ & 6 & 238.63 & & & & \\
\hline & $\mathrm{C} 2$ & 6 & 238.63 & 265.1 & 26.5 & 45.9 & 1.86 \\
\hline & $\mathrm{C} 3$ & 8 & 318.17 & & & & \\
\hline \multirow[t]{3}{*}{1.00} & D1 & 19 & 755.65 & & & & \\
\hline & D2 & 11 & 437.48 & 583.3 & 92.8 & 160.7 & 5.29 \\
\hline & D3 & 14 & 556.79 & & & & \\
\hline \multirow[t]{3}{*}{1.25} & E1 & 20 & 795.42 & & & & \\
\hline & E2 & 17 & 676.11 & 835 & 105 & 182 & 8 \\
\hline & E3 & 26 & 1034.05 & & & & \\
\hline \multirow[t]{3}{*}{1.50} & F1 & 12 & 477.25 & & & & \\
\hline & F2 & 17 & 676.11 & 517 & 82.8 & 143.4 & 4.57 \\
\hline & F3 & 10 & 397.71 & & & & \\
\hline \multirow[t]{3}{*}{1.75} & G1 & 20 & 795.42 & & & & \\
\hline & G2 & 14 & 556.79 & 636.3 & 79.5 & 137.8 & 5.86 \\
\hline & G3 & 14 & 556.79 & & & & \\
\hline \multirow[t]{3}{*}{2.00} & $\mathrm{H} 1$ & 41 & 1630.61 & & & & \\
\hline & $\mathrm{H} 2$ & 63 & 2505.57 & 1989 & 265 & 459 & 20.43 \\
\hline & $\mathrm{H} 3$ & 46 & 1829.47 & & & & \\
\hline
\end{tabular}

\section{Results and discussion}

Results presented in Fig. 2 showed that the number of blows required to produce the first crack increased with an increase in the fiber volume and was especially prominent at higher values of fiber. On the other hand, in concrete without fiber addition the number of blows to produce first and damage cracks were considerably less, an average of 2.33 in both cases. The absence of fiber to produce resistance, lead to the appearance of flexural crack (Fig. 1b) which is always taken as the first as well as damage cracks. At the first blow, the specimen was still stable and intact, but immediately after the impact of the second or third blow full flexural crack appears. However, in concretes with fiber addition, the first crack is mostly taken as the appearance of hairline cracks after impact which mostly starts from weak zones where the presence of the fiber is not felt, the smooth sides of the cylinder or crevices generated during the cutting process. The maximum average number of blows observed to produce damage cracks was 50 blows at fiber addition level of $2 \%$ which can be seen in Fig. 2. This produced a corresponding trend in the amount of impact energies for the first crack and damage cracks respectively. This could be attributed to energy absorption capacity of fibers which manifest at higher fiber addition level.

It is known that steel fiber addition has more effect on the toughness characteristics which is the energy absorbed by the specimen covered by area under the load - deformation curve, than on strength characteristics and in this case impact energy as well. The number of blows to fiber addition levels shows a considerable increase in the number of blows required to either induce crack or damage the specimen beyond addition level of $1 \%$ and peaked at $2 \%$, specimens with $2 \%$ fiber volume receiving the highest impact energies compared with other specimens with lower percentages of steel fiber. 
It was also observed that failure of the specimens resulted in the separation of the fiber from the matrix despite the matrix being stronger, and in some cases the fibers could be seen vertically aligned from the matrix. This could be attributed to preferential alignment of fibers during placing of the mix in the cylindrical mould. There is no much room for maneuver so that the fibers could be placed in such a manner as to carry the load after the first crack. More so, the cylinders were cut perpendicular to the direction of the fibers.

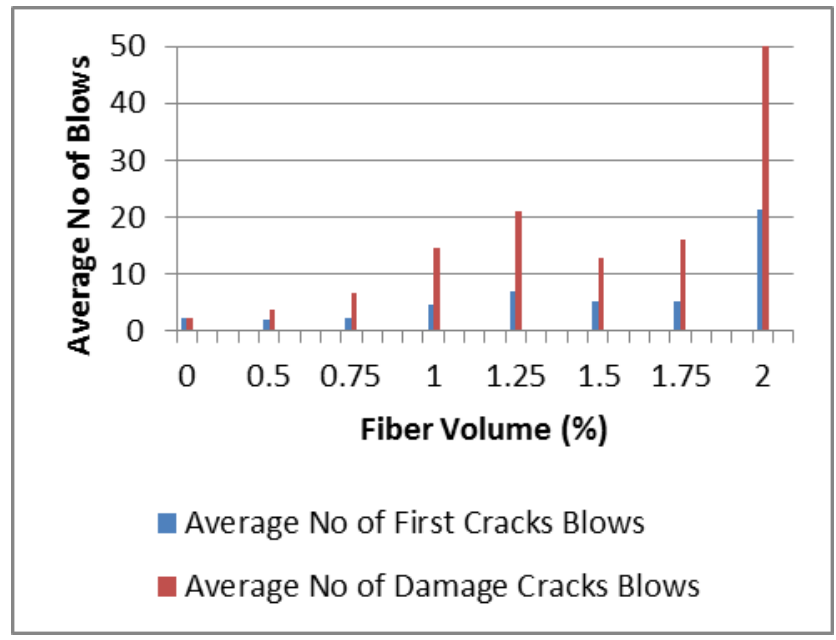

Figure 2. Relationship between numbers of blows against fiber volume.

If the cylinders had been cut in the diametral direction, probably this problem might not occur, alternatively, prisms should be used instead of cylinders. The graph of impact energy versus fiber addition levels (Fig. 3) indicated an increase the addition levels resulted in energy absorption capacity, though somewhere at $1.5 \%$ addition, there was a decline in both the first and damage cracks energy but which later rises.

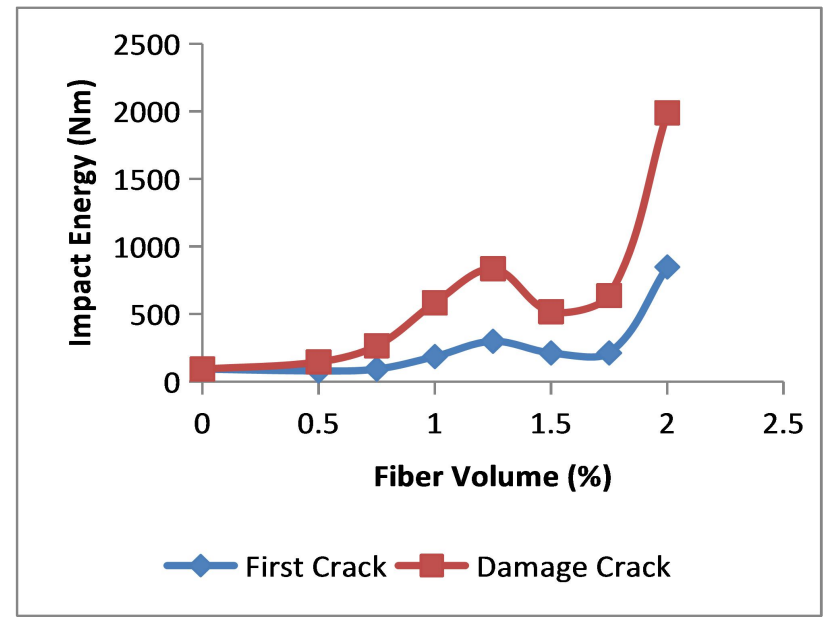

Figure 3. Relationship between impact energy against fiber volume.

\section{Conclusion}

An evaluation of the long - term exposure of concrete specimens under environmental weather conditions on the impact resistance of HPSFC was conducted and the following conclusion has been arrived at:

Long - term exposure to weather elements and increase in fiber percentage increases the impact resistance of the concrete slowly at the beginning but substantially at up to $2 \%$ fiber addition. The impact energy effectiveness at first and damage cracks were 8 times and 20 times respectively at $2 \%$.

\section{References}

1. ACI 544.1R-96: 2001 State-of-the-Art Report on Fiber Reinforced Concrete American Concrete Institute Farmington Hills MI USA

2. Ö. Eren, K. Marar and T. Celik (1999) Effects of Silica Fume and Steel Fibers on Some Mechanical Properties of High-Strength Fiber-Reinforced Concrete Journal of Testing and Evaluation 27, 380 387

3. K. .Marar, Ö. Eren and T. Celik (2001) Relationship between impact energy and compression toughness energy of high-strength fiber-reinforced concrete Materials Letters 47, 297-304

4. P. S. Song, J. C. Wu, S. Hwang and B. C. Sheu (2005) Statistical analysis of impact strength and strength reliability of steel-polypropylene hybrid fiberreinforced concrete Construction and Building Materials 19, 1-9

5. K. H. Mo, S. P. Yap, U. J. Alengaram, M. Z. Jumaat and C. H. Bu (2014) Impact resistance of hybrid fibre-reinforced oil palm shell concrete Construction and Building Materials 50, 499-507

6. ACI 544.2R-89: 1988 Measurement of Properties of Fiber Reinforced Concrete American Concrete Institute Farmington Hills MI USA

7. P-C. Aitcin (1998) HighPerformance Concrete E \& FN SPON New York NY $\mathrm{U}$ 